\title{
Comparative Efficacy of Metacognitive therapy versus Cognitive- Behavioral therapy on reducing the metacognitive beliefs, fusion beliefs, stop signals and control/threat beliefs in patient with washing obsession.
}

\author{
Fatemeh Ayetmehr ${ }^{1 *}$, Saman Sadeghpour ${ }^{2}$ \\ 1. MSc. in Clinical Psychology, Kharazmi University. (Corresponding Author) \\ Fatemeayatmehr@gmail.com tel: +989144058643 \\ 2. MSc in Clinical Psychology, Kharazmi University.
}

\begin{abstract}
Background: Due to the complex nature and varied symptoms of obsessive-compulsive disorder, different treatments have been used for OCD.

Objective: The aim of this study was comparing the efficacy of cognitive-behavior therapy (CBT) and meta-cognitive therapy (MCT) on reducing metacognitive beliefs, fusion beliefs, internal stop signals and control/threat beliefs.

Method: To do so, 6 women with OCD (pure washing), were selected based on the structured clinical interview for DSM-IV (SCID), and were assigned randomly to CBT or MCT group. In each group, patients received the relevant therapies in 12 one-hour sessions. Research tools included Obsessive-Compulsive Inventory (OCI-R), stop signals questionnaire (SSQ), thought fusion inventory (TFI) and metacognition questionnaire-30 (MCQ-30) that were completed by patients in pretest, posttest, follow up 1 and follow up 2. Finally, data was analyzed both individually and in group. In individual analysis, we used diagrams, visual analysis and calculating the effect size, while in group analysis, the analysis of variance with one between group factor (two group of therapies) and one within group factor (time of tests) was used.
\end{abstract}

Result: The results indicated that metacognitive therapy was more effective than cognitivebehavioral therapy in reducing the metacognitive beliefs, fusion beliefs and internal stop signals. However, cognitive-behavioral therapy was more effective than metacognitive therapy in reducing the control/threat beliefs.

Conclusion: Considering these results, it can be suggested that overall, metacognitive therapy is more appropriate for reducing the obsessive symptoms. However, definitive conclusion about the efficacy of these therapies requires more studies.

Keywords: Obsession, Metacognitive therapy, Cognitive-behavioral therapy, Fusion belies, Internal stop signal 


\title{
مقايسه كار آمدى درمان فراشناختى و درمان شناختى - رفتارى در كاهش باورهاى

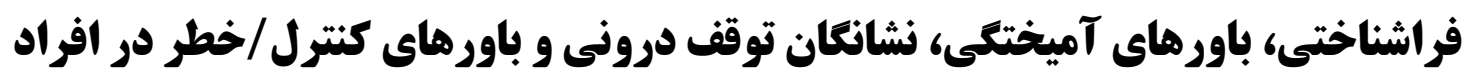 وسواس شستشو
}

\author{
فاطمه آيت مهر 1"، سامان صادق يور2

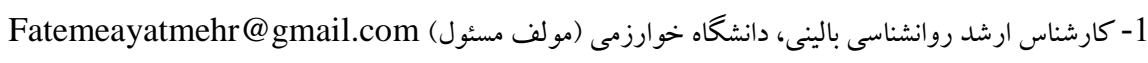

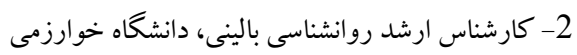

مقدمه: با توجه به ماهيت يِيجِيده و نشانگان متنوع اختلال وسواسى - اجبارى، درمانهاى متفاوتى براى اين اختلال استفاده مى -

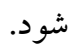
هدف: هدف يُؤهش حاضر مقايسه كارآمدى دو درمان شناختى- رفتارى و فراشناختى در كاهش باورهاى فراشناختى،

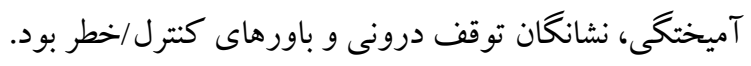

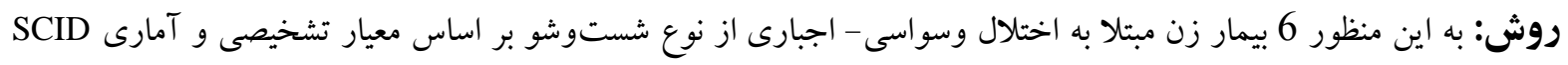

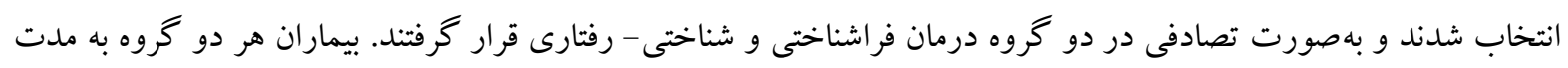

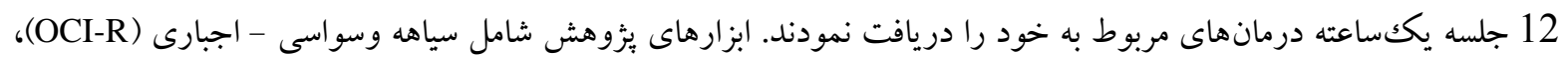

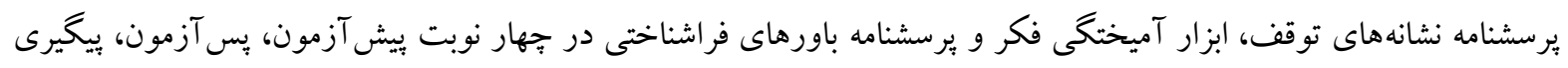

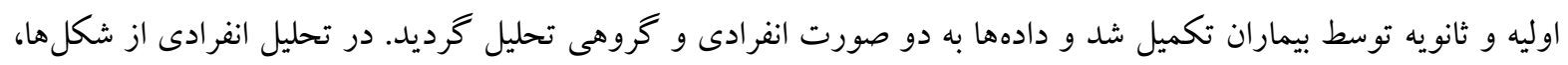

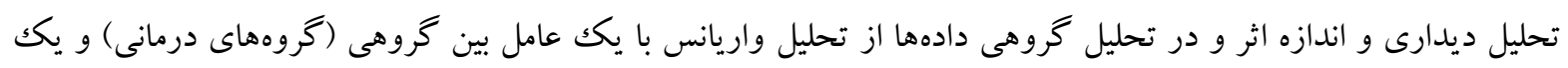
عامل درونى (زمان آزمونها) استفاده شد.

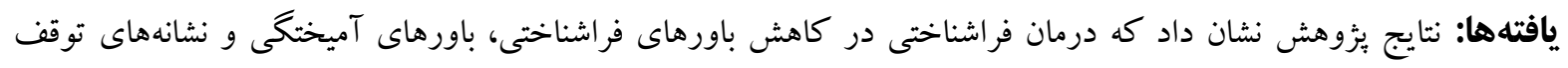

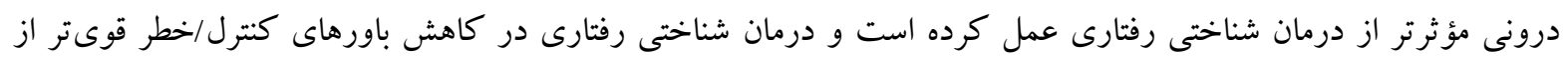
درمان فراشناختى عمل مى كند.

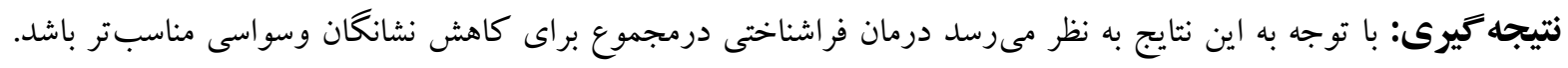

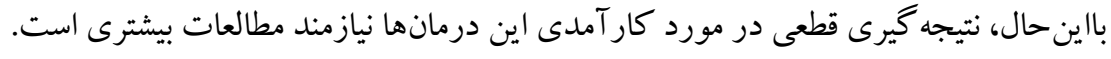

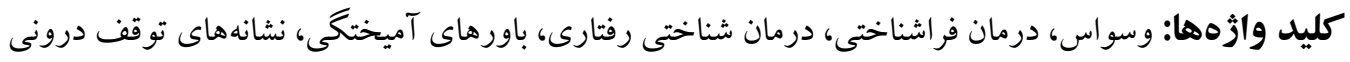


بازنخرىها، فرا تحليلها و پِارامترهاى عملى، درمان

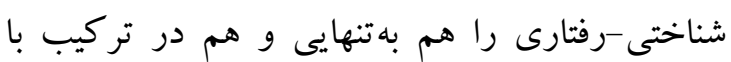

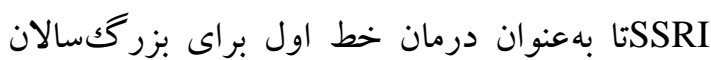
مبتلا به اختلال وسواسى-اجبارى معرفى مى كنند (بارتّ و همكاران، 2008؛ واتسون و و همكاران، 2009). باوجود جنين شواهدى تعداد قابل توجهى از

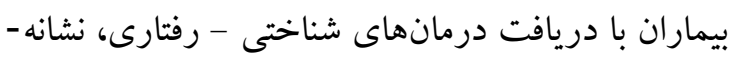
هاى خود را حفظ كردهاند و يا هيج بهبودى نداشتهاند

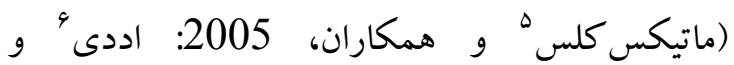
همكاران، 2004). در بززوهشى ديخر ولز و همكاران

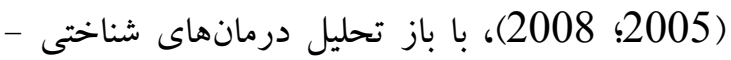

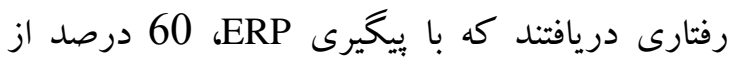

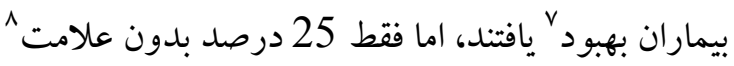

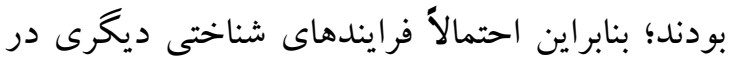
ايجاد و تداوم اين اختلال نقش دارند كه در درمان شناختى -رفتارى موردتوجه قرار نغخر فتهاند. رويكرد فراشناختى در تبيين OCD حوزه ديخرى از شناختها را مدنظر قرار داده است. ولز بهعنوان بنيان كذار اين رويكرد ادعا مى كند كه CBT به جالش با محتواى افكارى مى بردازد كه خود محصول فرايندهاى سطح بالا و بيّجيدهتر هستند درحالى كه

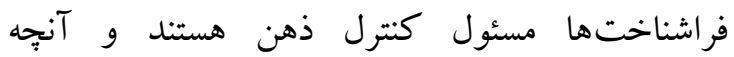
هيجانها و نحوهى كنترل آنها را تعيين مى كند، نه جيستى افكار فرد، بلكه جְگ همكاران، 2011). اين مدل شامل دو حيطه باورهاى إى فراشناختى مىشود: 1- باور درباره معنى و اهميت مداري افكار كه باورهاى آميختكى ناميده مىشود و 2- باور دربارهى كنترل افكار و انجام آيينمندىها و بهتبع آن

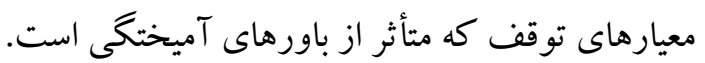

3. Barrett

4. Watson

5. Mataix-Cols

6. Eddy

7. Recovery

8. Asymptomatic

\section{مقلدمه}

اختلال وسواسى - اجبارى (OCD) با وسواسهاى

فكرى و /يا وسواسهاى عملى مشخص ميى مود. وسواس ذهنى شامل افكار، تكانها و تصاويرى است كه بهصورت مزاحم و ناخواسته تجربه مىشوند. وسواسهاى عملى، رفتارها و اعمال ذهنى تكرارى هستند كه فرد احساس مى كند در بِاسخ به افكار وسواسى و بر اساس قواعد غير منعطفى مجبور به انجام

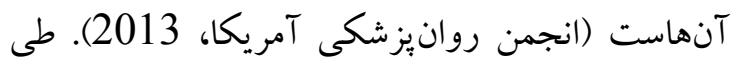

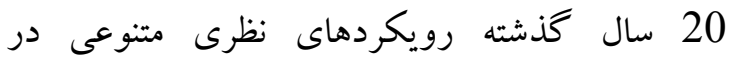
جهار جوب درمان شناختى -رفتارى شكل گرفتهاند كه بر نقش مؤلفههاى شناختى مختلف در ايجاد و تداوم اين اختلال تأكيد مىنمايند، در اين ميان مدل سالكووسكيس ' كه بر "احس مسئوليت در ارزيابى

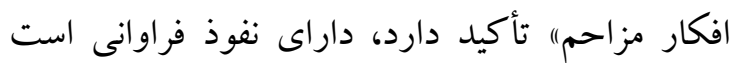

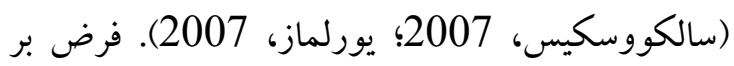
اين است كه اكر فرد در ارزيابى افكار مزاحمى كه بهصورت ناخهانى به ذهن خطور مى كنند، معنايى را به آنه

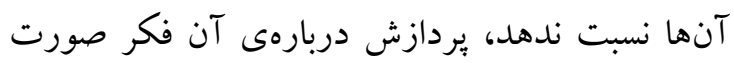

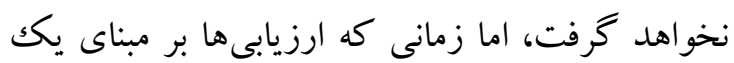
واكنش خاص مثل خطر آسيب و يا مسئوليت باشد، فر آيندهاى كنترل كردن و اجبارهاى بالينى در بيماران

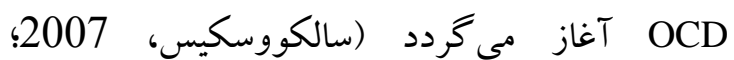
يورلماز، 2007؛ آبروموويتز، 2006). بنابراين از ديدگاه سالكووسكيس افكار وسواسى مزاحم به اين

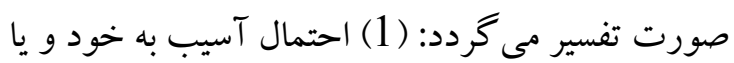
ديخرى وجود دارد، (2) فرد در برابر جنين آسيبى و يا در بيشخيرى از آن مسئول است. درمان در اين رويكرد آماج قرار دادن باورهاى شناختى بهويزه باورهايى با محتواى مسئوليت است.

1. Obsessive Compulsive Disorder (OCD) 2. Salkovskis 
اين معيارها بر آورده شدهاند يا خير، زمان بيشترى مى -

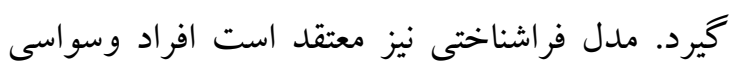
توقف آيينمندىهايشان را بر اساس معيارهاى درونى و ويزه خودشان تعيين مى كنند (مايرز و همكاران، 2009). مثلاً فردى با وسواس مرتبط با بيمارى، ممكن ودئ است براى رهايى از ميكروب، به شستن مكرر دستها

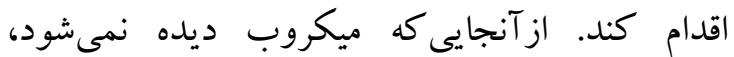
شخص ممكن است براى توقف آيين شستن دست، از قاعدهى احساس درستى ها يا شستن به تعداد دفعات

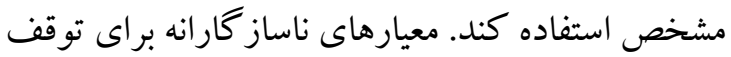

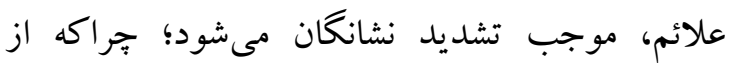

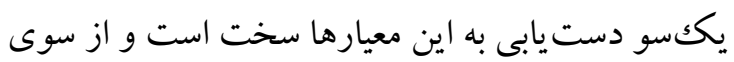
ديخر براى رفتارى كه بهنظور جلو گيرى از گسترش يكك رابطهى كاركردى و منعطف با افكار و احساسات تدار كك ديده شده است، شيوهى مناسبى نيست (مايرز و همكاران، 2009). اين نظريه كه علائم توقف در نشانگًان OCD نقش دارد، توسط وال و همكاران (2008) موردحمايت قرارگرفته است. آنها دريافتند كه افراد با وسواس شستشو، اغلب از معيارهاى ذهنى براى پايان دادن به عمل شستشو استفاده مى كنند و اهميت اين معيارها را حتى بيشتر از كنترل كردن

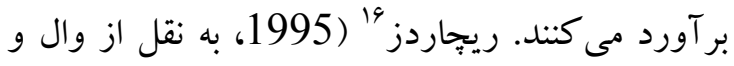
همكاران، 2008) نيز عنوان مى كند كه بيماران وسواسى براى تصميم گيرى در مورد بايان دادن به عمل وسواسى، بر حالات درونى مانند احساس درستى يا تهري

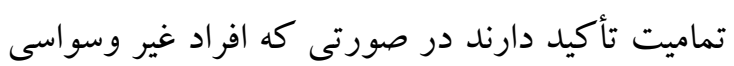
بر معيارهاى عينىتر (مانند صداى قفل شدن در براى جك كردن) تكيهدارند. از سوى ديخر، سالكووسكيس و همكاران (2000) معتقدند كه تفاوت بين افكار مزاحم نرمال و افكار

15. Feeling of Rightness 16 .Richards
باورهاى آميختخى اساس باورهاى فراشناختى را در اختلال وسواس تشكيل مىدهند. در اين مفهوم، افكار و اعمال در يكديخر تنيده شدهاند و افراد احساس مى كنند كه افكارشان، بهويزه افكار بيليدشان مى تواند رويدادهاى خارجى را تحت تأثير خود قرار دهد (سو گيرى احتمال) و يا طبق سو گيرى اخلاقى، افكار مزاحم ناخوشايند و يليد ازلحاظ اخلاقى معادل با انجام آن عمل تلقى مىشود؛ مطالعات ارتباط مثبت و و معنادارى بين باورهاى آميختخى و علائم وسواسى نشان

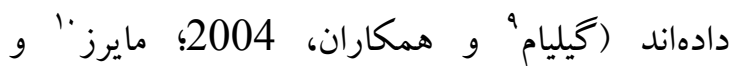
همكاران، 2009؛ سولم" و همكاران، 2010).

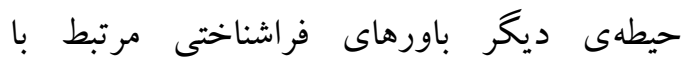
وسواس، باورهاى مرتبط با لزوم انجام آيينمندى است.

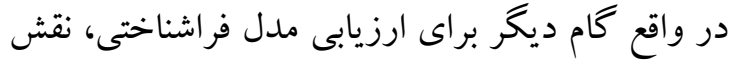
باورهاى فراشناختى در معيارهاى توقف است. سالكووسكيس (1999) معتقد است كه يك باسخ معمول به ترس ناشى از احساس مسئوليت در برابر

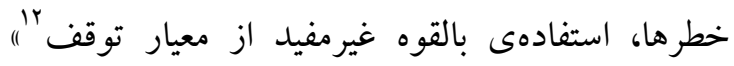
است؛ كه ضمن آن فرد براى تصميم گيرى مبنى بر برهير اينكه آيا فعاليتى را بهطور كامل انجام داده است يا نه فعالانه درصدد دستيابى به يكك حالت ذهنى يا هيجانى است. اين مفهوم شامل جستجوى عامدانهى يكك حالت خلقى خاص، يكك حس رضايت و تماميت و احساس "كاملاً درست "َ'" است؛ كه به معناى روشى براى تصميم گيرى مناسب در مورد توقف رفتار است

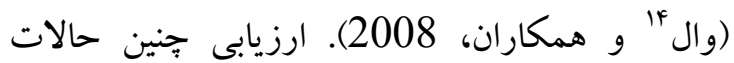
درونى در مقايسه با دروندادهاى حسى براى فرد مشكلتر است و لذا تصميم گيرى در مورد اينكه آيا

9. Gwilliam

10. Myers

11. Solem

12. Stop Criteria

13 Just Right

14.Wahl 
״س از درمان و در مرحلهى بيگيرى در مقياسهاى اختلال وسواسى-اجبارى و فراشناخت، بهبودى قابل توجّهاى نشان داد. مطالعات اندوز و همكاران (2013) و ريس و همكاران (2008) نيز كار آمدى MCT را در هدر كاهش نشانهاى OCD تأييد كردهاند. با در نظر داشتن اين كه درمان فراشناختى، درمانى كوتاه مدت و فشرده محسوب مىشود، در صورتى كه يافتهاى ئزوهشى اثربخشى آن را در درمان اختلال وسواسى - اجبارى تائيد نمايد، مىتواند ززينهى مطلوبى براى درمان

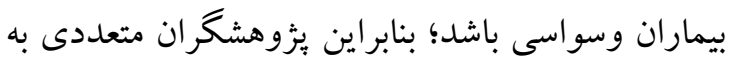

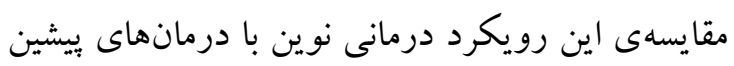

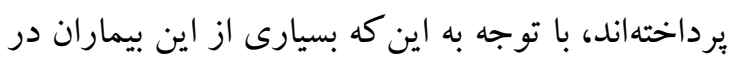
برابر فنون شناختدرمانى مقاومت مى كنند و نيز نظر به تنوع نشانگانى زياد در OCD، شايد درمان فراشناختى

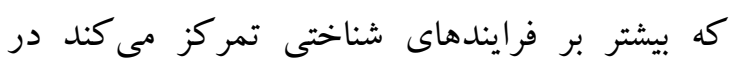
مديريت اين نوع بيماران مؤثر واقع شود. از همين رو يثزوهش حاضر، با هدف مقايسهى كارآمدى درمان فراشناختى و درمان شناختى -رفتارى در كاهش نشانه-

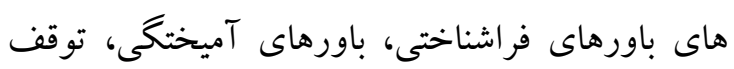
درونى و باورهاى كنترل/خطر انجام شده است.

\section{روش}

مدل آمارى در اين طرح بثوهشى مدل آميخته از اثرهاى بين آزمودنى و درون آزمودنى است كه از طريق مدل تكك آزمودنى انجام مى گيرد. لازم به ذكر است بخشى از سنجش هر جلسه صورت خواهد يذيرفت و بخش ديخر آن همان گونه كه در جدول شمارهى 1 مشاهده مى كنيد شامل جهار اندازه

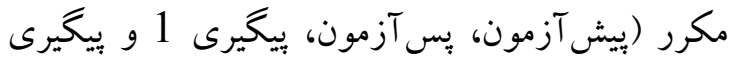

وسواسى بالينى نه بر وقوع يا حتى كنترل يذيرى/كنترل نإِذيرى افكار مزاحم، بلكه بيشتر بر تفسيرى متكى است كه افراد وسواسى از وقوع و محتواى افكار

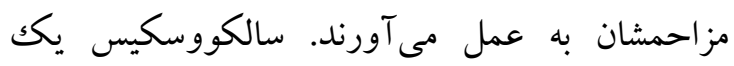
تحليل شناختى رفتارى از OCD ارائه مىدهد كه در آن

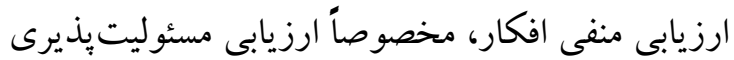
منجر به رفتارهاى اجبارى مىشود. اين تحليل فرض إضى مى كند كه افرادى كه مشكلات وسواسى دارند، افكار مزاحم يا تكانهاى عادى را كه در ساير افراد هم رخ مىدهد، بهعنوان يكك خطر براى خود و و ديخران

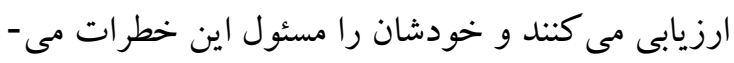
دانند.

از اين ديدگاه، در مشكلات وسواسى، وقوع افكار مزاحم، بدين گونه تفسير مىشود كه فرد در آسيب

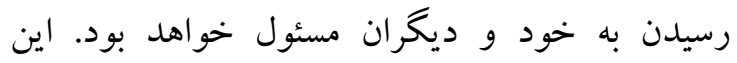
ارزيابى منجر به خلق ناساز گار (اضطراب و افسردگى) و نيز تحريكك و تصميم به درگير شدن در رفتارهاى

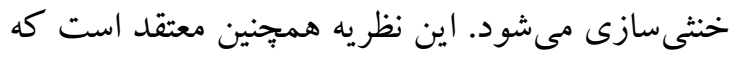
منشأ ارزيابىهاى منفى، فرضئهاى هيى ياد كر فته شده است. جنين مفروضاتى اغلب بهعنوان راههاى ساز گارانه براى مقابله با تجارب اوليه شكل مى گيرند و بعدها زمانى كهو توسط وقايع مهم فعال شوند، مىتوانند آغازگر مشكلات وسواسى باشند. اين مفروضات نه تنها شامل باورهايى درباره آسيب و مسئوليت هستند، بلكه معنا و ماهيت افكار مز احم را نيز در برمى كيرند.

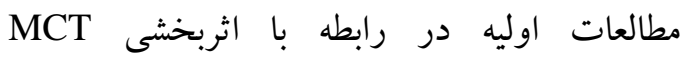
اميدبخش به نظر مىرسد. فيشر و همكاران (2008) با استفاده از طرح سرىهاى مورد، اثرات درمان

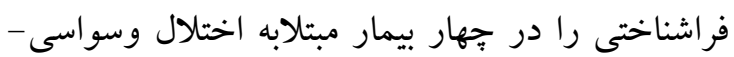
اجبارى مورد ارزيابى قراردادند. نمرات همهى بيماران 
جدول 1: اندازهزيرىهاى مكرر در طرح يزوهشى

\begin{tabular}{|c|c|c|c|c|}
\hline & Pretest & Posttest & Follow1 & Follow2 \\
\hline CBT & & & & \\
\hline MCT & & & & \\
\hline
\end{tabular}

شناختى ديخرى نباشند، درمان رفتـارى يـا CT را در دو

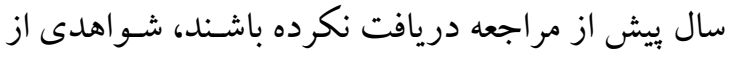
بيمارى سـايكو تيكك يـا جسـمانى و يـا شـرايط بــنى يـا دارويى ناشى از اضطراب وجـود نداشـته باشـد، بــدون دارو يا در شرايط دارويى ثابت باشند (سه مـاه درمـان و سه ماه بيگيرى بدون تغيير در دوز و نوع دارو). شـرايط خروج از درمان شامل تشخيص اختلالات سـايكو تيكى، عدم تمايل به ادامهى درمان و تغيير در شـرايط دارويسى

ابزار

نسخه ويراست شلده سياهه وسواسى - اجبارى

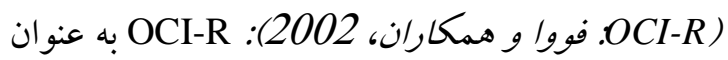

مقياسى از نشانهاى وسواسى-اجبارى به كار مىرود. فتى، محمدى و زمانى (1387) اين مقياس را در يكك جمعيت دانشجويى در ايران هنجاريابى كردند. نتايج يُزوهش مذكور، همسانى درونى مطلوبى به دست داد كه با ضريب آلفاى كرونباخ محاسبه شد (در دامنه 0/5 تا 0/72). علاوه بر اين، ساختار شش عاملى كه در يُزوهش اصلى به دست آمده بود، به وسيله تحليل عاملى تأييدى به تائيد رسيد.

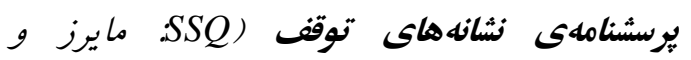

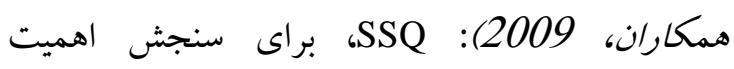
معيارهاى توقف اصلى براى تصميم گيرى جهت متوقف كردن آيينمندىها ايجاد شده است. يرسشنامه برهي شامل 12 آيتم با نمره گذارى صفر تا 4 است. بايايى آزمون-بازآزمون بعد از سه ماه براى SSQ، نشان داد كه مى تواند با ضريب مشتر كك 0.62 قابل قبول باشد. ابزار آميختكى فكر (TFI: ولز و همكاران، 2001): اين ابزار براى اندازهگيرى سه نوع آميختخى فكر تصريحشده در مدل فرا شناختى (آميختكى فكر -عمل،
در اين ئزوش 6 بيمار بهصورت در دسترس انتخاب شدند و بهصورت تصادفى در درمانهاى CBT

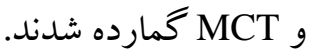
براى تحليل دادههاى اين بثزوهش از روش تحليل واريانس با يكك عامل بين گروهى (كروههاى درمانى)

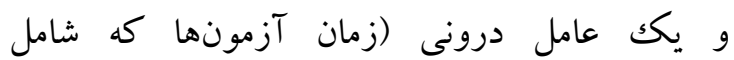
يبش آزمون، بس آزمون، بيگيرى اوليه و ثانويه) استفاده مىشود. فرازوفرود متغير وابسته بايه داورى ميزان تغيير به شمار مىرود. افزون بر اين از ملاكك معنادارى بالينى

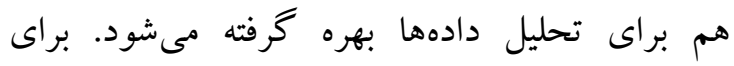
جينى سازى ميز ان بهبودى از فرمول زير مىشود: $A \%=\frac{A 0-A 1}{A 0}$

در فرمول فوق، A0 مشكل آماجى در جلسهى اول، A1 مشكل آماجى در جلسهى آخر و r\% ميز ان بهبودى

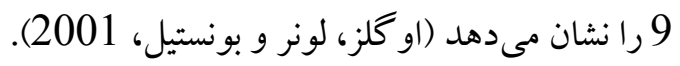
شر كت كنند كان جامعهى آمارى اين بثزوهش، تمام بيمـاران مبـتلا بـــ

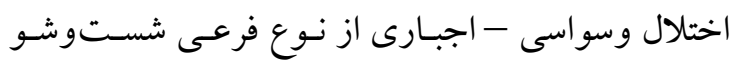
بود. نمونه از ميان افرادى كه در سه سال كذشته به يك اجك مركـز درمسانى در شهر تبريـز مراجعـه كـرده بودنسـد،

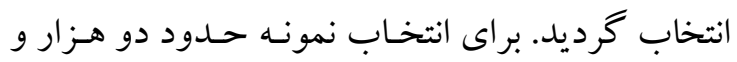
קانصد يروندهى موجود در اين مركز موردمطالعه قرار

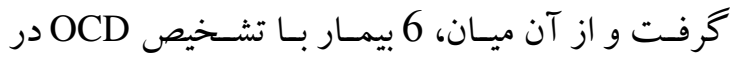
محور يكك و بدون آلودگى در محسور دو انتخـاب و بـه صورت تصادفى در گروههـاى MCT و CBT گمارده شد. ملاككهاى ورود بيماران به فرايند يُزوهش عبارت بود از: وسواس و اجبارها را تجربه كرده باشند. به مدت يكك سال كذشته OCD داشته باشند، 18-65 سال سن ونس داشته باشـند، هـم زمـان در حـال دريافت درمـان روان 
كلمبيا توسط ساكتين، ويتال، مككلين تدوين شده است، آماده شد. تكنيككهاى شناختى - رفتارى ارائه شده در اين مجموعه بر اساس كارهاى افرادى نظير وناين و همكاران (1994)، فريستون و همكاران

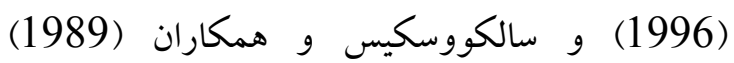
קايه گذارى شده است.

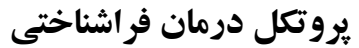

درمان فراشناختى براى بيماران مبتلابه اختلال وسواسى - اجبارى توسط آدريان ولز (2008) ايجاد

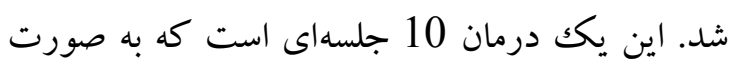
هفتكى و به مدت 45 الى 60 دقيقه بر گزار مىشود. قدم اول در اين درمان تشويق بيمار براى آكاهى از نقش فراشناخت ها در تداوم نشانهاى بيمارى است. در واقع هدف اين است كه بيمار بهجاى اين كه با افكار خود دربارهى وسواسها و اجبارها بهعنوان واقعيت

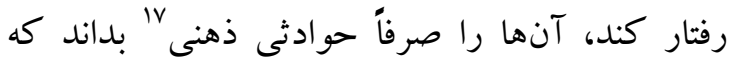
نيازمند بردازش ذهنى بيشترى نيست (فيشر و همكاران، . (2008

\section{شيوهى اجرا}

״س از ارزيابى و انتخاب بيماران، آنها را بهصورت تصادفى در دو گروه قرارداديم، هر يكك از بيماران بعد از تكميل ييش آزمون بهصورت انفرادى 10 - 12 جلسه درمان 60 دقيقهاى شناختى - رفتارى يا فراشناختى دريافت نمودند. يكك ماه بعد از اتمام

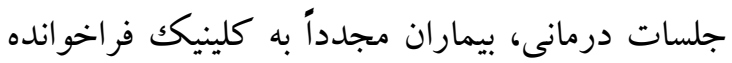
شدند و بررسى كوتاهى طى يكك جلسه نيم ساعتى به عمل آمد. در اين جلسه به سؤالات بيماران در حفظ بـ بهبودى يس از درمان ياسخ داده شد. جلسهاى مشابه سه

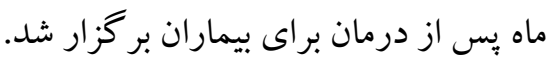

17. Mental Event
آميختخى فكر-رويداد و آميختكى فكر-شى) طراحىشده است و شامل 14 آيتم در طيف صفر تا صد نمرهاى است. جىويليام، ولز، كارت رايت-هاتون (2004) شواهد مقدماتى و بايايى به دست آوردند كه آنه از اعتبار همخرا و تفكيك كننده آن حمايت مى كرد (سولم و همكاران، 2008). اين پِرسشنامه در ايران توسط خرمدل و همكاران (1389) در جمعيت دانشجويى هنجاريابى شده است. تحليل يايايى همسانى درونى، ضريب آلفا را براى عامل كلى 87 درصد نشان

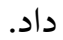

يرسشنامهى باورهاى فراشناختى (MCQ-30): يكك مقياس خود گزارشى 30 سؤالى است كه توسط ولز ئز ساخته شده و شامل 5 خرده مقياس باورهاى مثبت

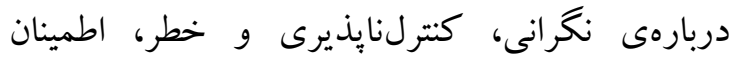
شناختى، نياز به كنترل افكار و خودآكاهى شناختى است. سؤالات اين برسشنامه در مقياس 4 درجهاى ليكرت نمره گذارى مىشود. اعتبار اين برسشنامه در دامنهاى بين 0/72 تا 0/93 گز ارش شده است. در ايران شيرين زاده دستخردى و همكاران (1387، به نقل از آيت مهر، 1392) همسانى درونى اين آزمون را براى كل خرده مقياسها 0/91 ززارش كردهاند. همجينين محمدخانى و مظلوم (1389) و محمدخانى و فرجاد

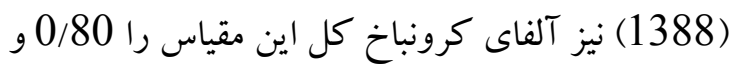
براى خرده مقياس هاى آن در دامنهى 0/53 تا 0/83 بدست آوردهاند. آلفاى كرونباخ اين مقياس درد درد يزوهش حاضر 0/77 بهدست آمد. يروتكل درمان شناختى - رفتارى راهنماى درمان شناختى - رفتارى بثزوهش حاض حاضرى

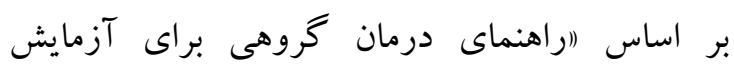
كنترلشده در اختلال وسواسى- اجبارى" كه بهمنظور مقايسه روش درمانى شناختى - رفتارى با روش درمان رفتارى (مواجهه و ويشخيرى از باسخ) در دانشخاه 


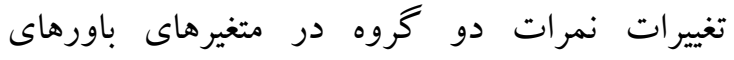

فراشناختى، باورهاى مرتبط با TAF، نشانهاى توقف

يافتهها

درونى و باورهاى كنترل/خطر برداختهايم. جدول 2

يزٔوهش حاضر باهدف مقايسه درمان فراشناختى و روند كلى اين تغيير ات را نشان مىدهد.

درمان شناختى-رفتارى در كاهش باورهاى فراشناختى،

باورهاى مرتبط با TAF، توقف درونى و باورهاى

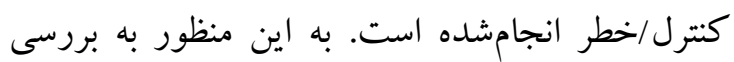

جدول 2: نمرات بيمار ان دو كروه در باورهاى فراشناختى، آميختكى، نشانهاى توقف درونى و كنترل فكر اخطر از

\begin{tabular}{|c|c|c|c|c|c|c|c|}
\hline $\begin{array}{l}\text { بر آورد خطر } \\
\text { OBQ }\end{array}$ & $\begin{array}{l}\text { كنترل فكر } \\
\text { OBQ }\end{array}$ & نشانه هاى توقف & باورهاى & فراورهاى & & & \\
\hline 16 & 26 & 34 & 210 & 32 & بيش آزمون & بيمار 1 & $\begin{array}{r}\text { گروه } \\
\text { MCT }\end{array}$ \\
\hline 11 & 21 & 19 & 170 & 32 & يִ آزمون & & \\
\hline 1 & 21 & 19 & 170 & 30 & بيخيرى بس از 1 ماه & & \\
\hline 3 & 24 & 18 & 150 & 25 & بيخيرى بس از 3 ماه & & \\
\hline 18 & 19 & 40 & 290 & 69 & ييش آزمون & بيمار 2 & $\begin{array}{r}\text { گروه } \\
\text { MCT }\end{array}$ \\
\hline 14 & 12 & 29 & 140 & 63 & يس آزمون & & \\
\hline 3 & 12 & 24 & 130 & 59 & بييخيرى بس از 1 ماه & & \\
\hline 3 & 12 & 24 & 130 & 59 & بيخيرى بس از 3 ماه & & \\
\hline 11 & 22 & 34 & 680 & 51 & يُش آزمون & بيمار 3 & $\begin{array}{r}\text { گرووه } \\
\text { MCT }\end{array}$ \\
\hline 6 & 18 & 19 & 330 & 49 & يس آزمون & & \\
\hline 1 & 18 & 19 & 280 & 48 & بييخيرى بس از 1 ماه & & \\
\hline 0 & 16 & 18 & 210 & 43 & ييخيرى پِ از 3 ماه & & \\
\hline 10 & 19 & 36 & 170 & 54 & يِيش آزمون & بيمار 4 & $\begin{array}{c}\text { گروه } \\
\text { CBT }\end{array}$ \\
\hline 4 & 9 & 3 & 140 & 50 & يس آزمون & & \\
\hline 3 & 7 & 2 & 140 & 46 & بييخيرى بِ از 1 ماه & & \\
\hline 0 & 0 & 1 & 140 & 37 & بيخيرى بس از 3 ماه & & \\
\hline 26 & 29 & 15 & 590 & 69 & يُش آزمون & بيمار 5 & $\begin{array}{c}\text { گروه } \\
\text { CBT }\end{array}$ \\
\hline 19 & 27 & 15 & 450 & 69 & يس آزمون & & \\
\hline 2 & 27 & 11 & 430 & 69 & بيخيرى يس از 1 ماه & & \\
\hline 2 & 24 & 20 & 450 & 70 & بيخيرى بِ از 3 ماه & & \\
\hline 18 & 26 & 35 & 0 & 47 & يُش آزمون & بيمار 6 & $\begin{array}{r}\text { كروه } \\
\text { CBT }\end{array}$ \\
\hline 13 & 19 & 20 & 0 & 47 & پِ آزمون & & \\
\hline 6 & 17 & 14 & 0 & 43 & بيخيرى يس از 1 ماه & & \\
\hline 0 & 8 & 14 & 0 & 40 & بيخيرى يس از 3 ماه & & \\
\hline
\end{tabular}




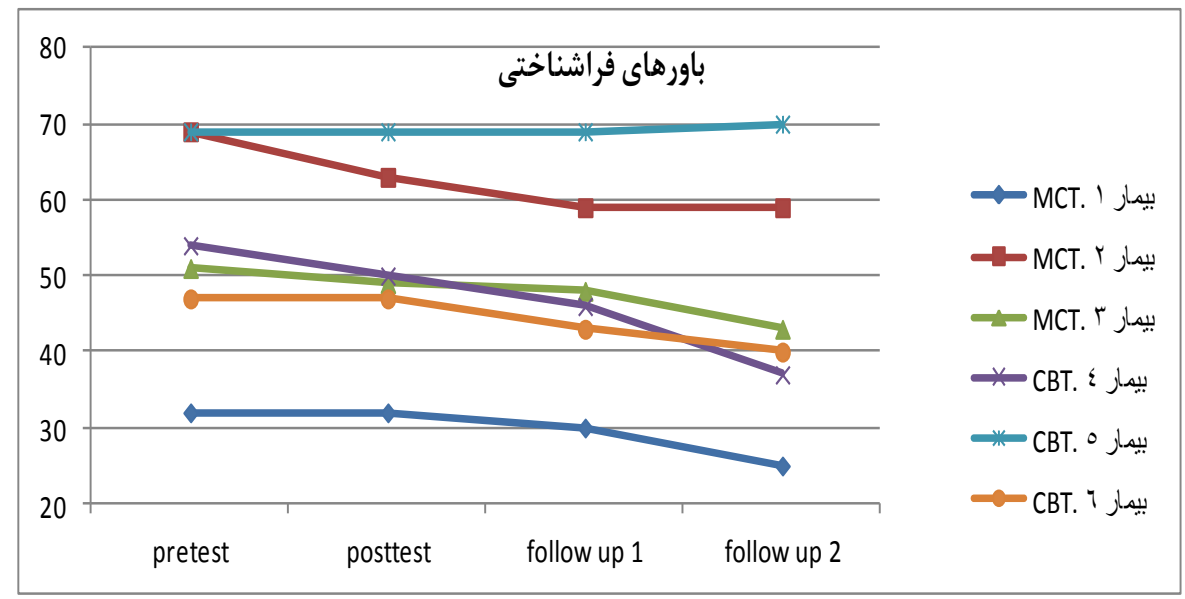

شكل 1: تغيير ات نمرات باورهاى فراشناختى در بيماران دو كروه MCT و CBT

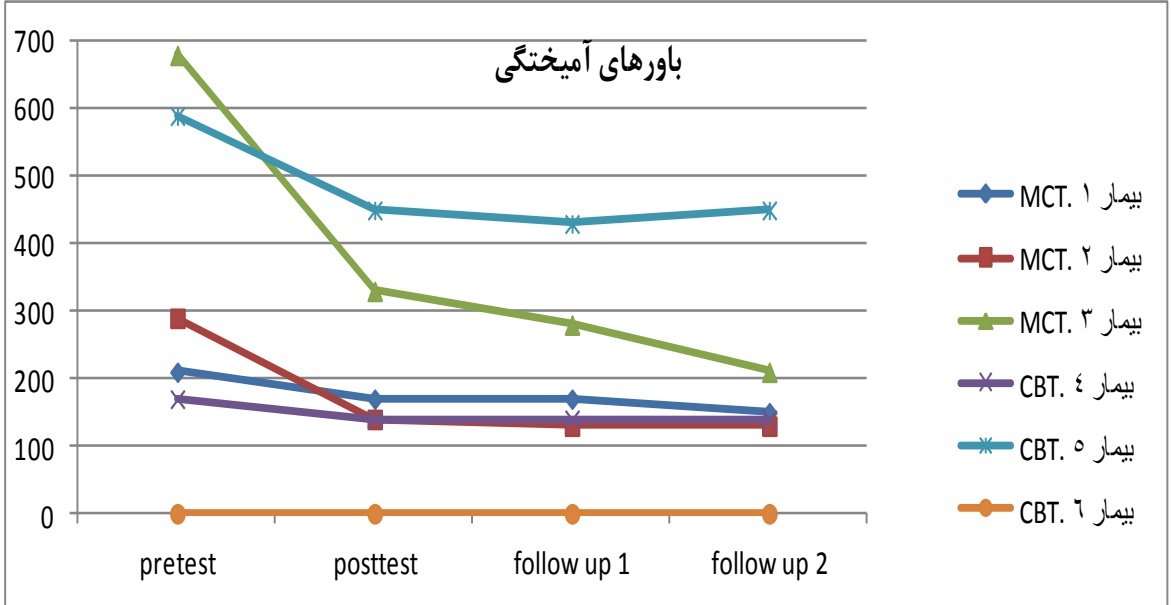

شكل 2: تغييرات نمرات باورهاى آميختكى در بيماران دو كروه MCT و CBT

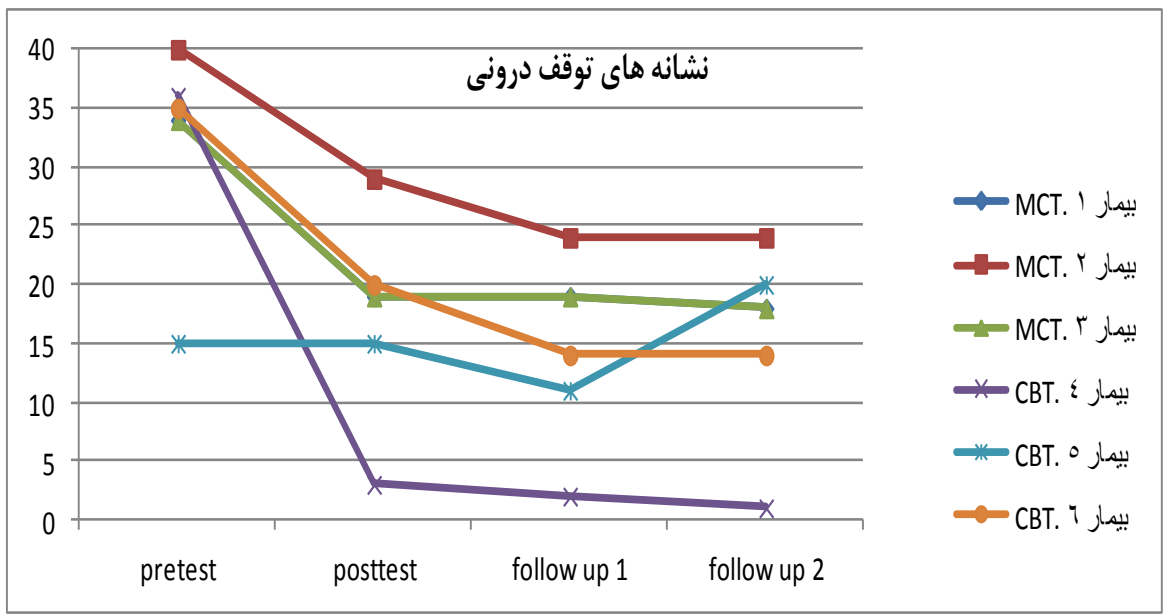

شكل 3: تغييرات نمر ات نشانههاى توقف درونى در بيماران دو كروه MCT و CBT

مجله روانشناسى و روان بزشكى شناخت، سال بنجم، شماره 1، بهار 1397، 17-1 


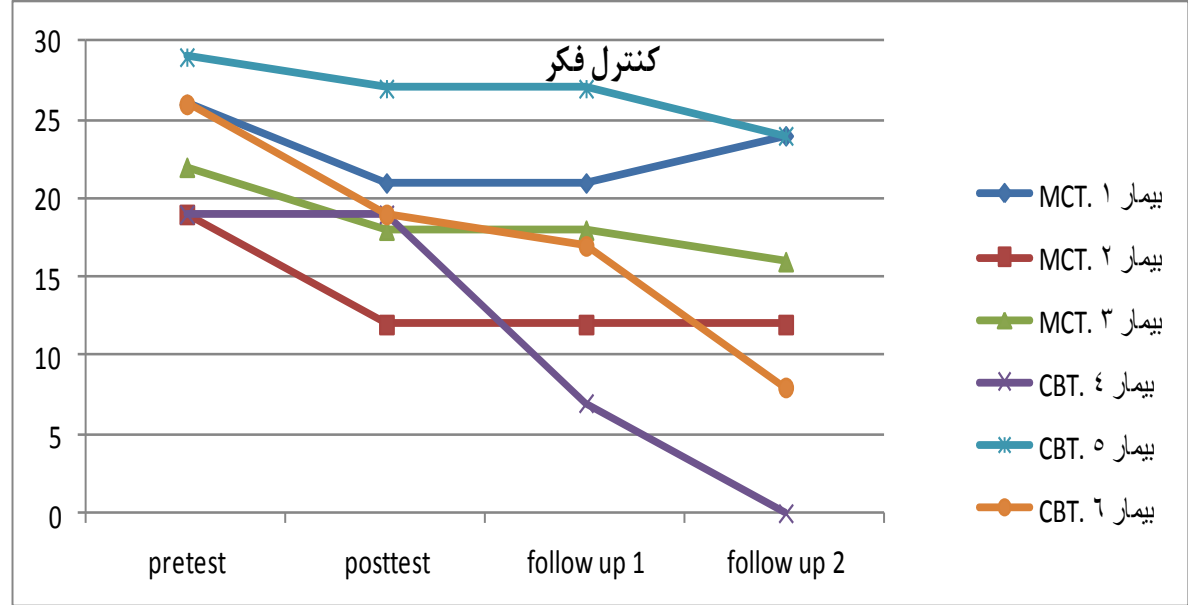

شكل 4: تغييرات نمرات كنترل فكر OBQ در بيماران دو كروه MCT و CBT

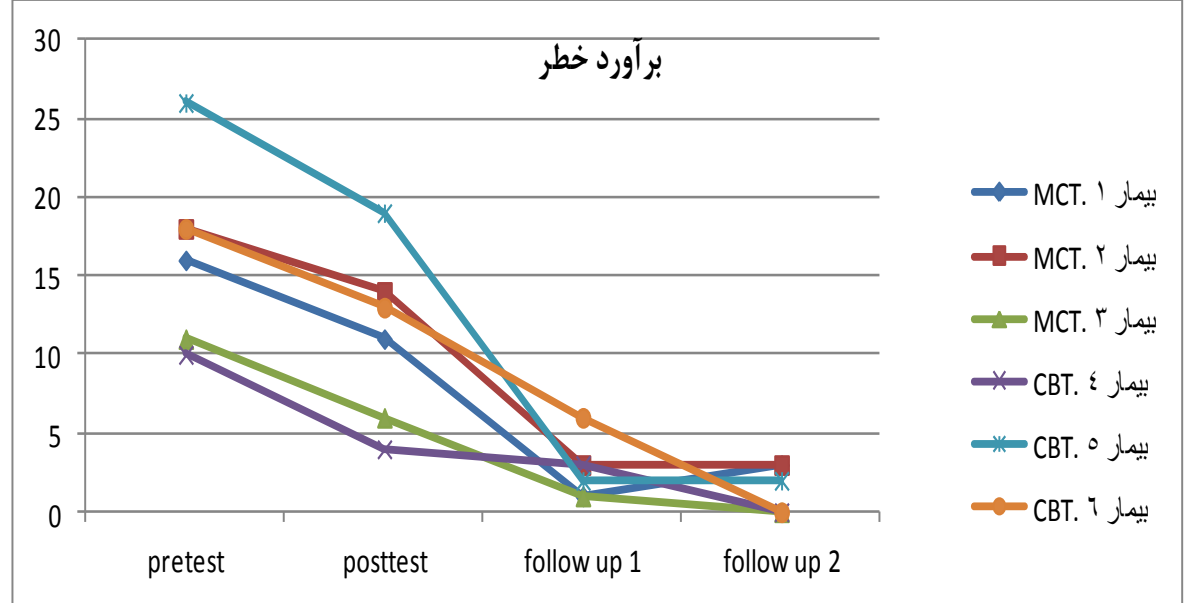

شكل 5: تغييرات نمرات بر آورد خطر OBQ در بيماران دو كروه MCT و CBT

آميختخى، نشانهاى توقف درونى و زير مقياس كنترل فكر اخطر است. در ادامه بهمنظور بررسى دقيقتر، شاخص اندازه اثر دو درمان MCT و CBT را در كاهش تككتك متغيرهاى بئوهش بررسى مى كنيم.
همانطور كه در جدول 2 و اشكال 1 تا 5 نشان دادهشده است، روند كلى تغييرات در علائم در هر دو درمان MCT و CBT كاهشى بوده است و نمرات بس آزمون و بيخيرى اوليه و ثانويه حاكى از كاهش

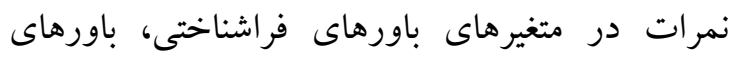


جدول 3: مقايسه اندازه اثر درمان، در كاهش نمره باورهاى فراشناختى، باورهاى آميختكى، توقف درونى، كنترل فكر و بر آورد

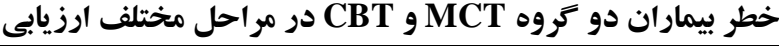

\begin{tabular}{|c|c|c|c|c|c|c|c|}
\hline \multicolumn{3}{|c|}{ درمان شناختى - رفتارى } & \multicolumn{3}{|c|}{ درمان فراشناختى } & & \\
\hline بيمار ششم & بيمار ينجم & بيمار جهارم & بيمار سوم & بيمار دوم & بيمار اول & مراحل & متغير هاى يُزوهش \\
\hline & & & & & & ارزيابى & \\
\hline 0 & 0 & 7.4 & 3.29 & 8 & 0 & بعد از درمان & باورهاى فراشناختى \\
\hline 8.51 & 0 & 14.84 & 5.88 & 14.49 & 6 & بيخيرى اوليه & \\
\hline 14.89 & -1.44 & 31.48 & 15.68 & 14.49 & 21.87 & بييخيرى ثانويه & \\
\hline 0 & 23.72 & 17.64 & 51.47 & 51.72 & 19.04 & بعد از درمان & باورهاى آميختكى \\
\hline 0 & 27.11 & 17.64 & 58.82 & 55.17 & 19.04 & ييخيرى اوليه & \\
\hline 0 & 23.72 & 17.64 & 69.11 & 55.17 & 28.57 & بيخيرى ثانويه & \\
\hline 42.85 & صفر & 91.66 & 44.11 & 27.5 & 44.11 & بعد از درمان & نشانهاى توقف درونى \\
\hline 60 & 26.66 & 94.44 & 44.11 & 40 & 44.11 & بيخيرى اوليه & \\
\hline 60 & -33.33 & 97.22 & 47.5 & 40 & 47.5 & يِيكيرى ثانويه & \\
\hline 26.92 & 6.89 & 52.63 & 18.18 & 36.84 & 19.23 & بعد از درمان & كنترل فكر \\
\hline 34.61 & 6.89 & 63.15 & 18.18 & 36.84 & 19.23 & بيخيرى اوليه & \\
\hline 69.23 & 6.89 & 100 & 27.27 & 36.84 & 7.69 & بيخيرى ثانويه & \\
\hline 27.72 & 26.92 & 60 & 83.33 & 22.22 & 31.25 & بعد از درمان & بر آورد خطر \\
\hline 53.84 & 92.3 & 70 & 90.90 & 78.75 & 93.75 & بيخيرى اوليه & \\
\hline 100 & 92.3 & 100 & 100 & 78.75 & 81.25 & يِيخيرى ثانويه & \\
\hline
\end{tabular}

14/84 است، مىتوان نتيجه گرفت كه MCT دران مجموع بيماران در كاهش نمرات باورهاى فراشناختى،

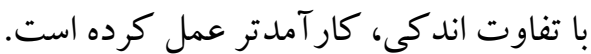

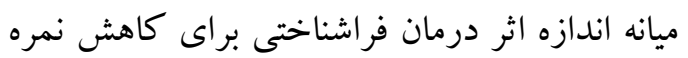

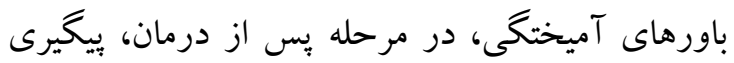

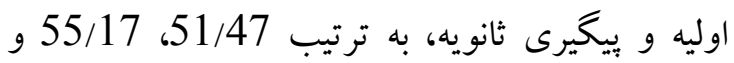
55/17 بوده است و اندازه اثر درمان شناختى -رفتارى ترئبي در اين متغير در مراحل بس از درمان، ييخيرى اوليه و

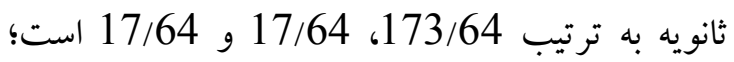
بنابراين در تمام مراحل درمانى اندازه اثر درمان فراشناختى بيش از CBT بود. با در نظر داشتن روند تغيير و تغييريذيرى نقاط دادهاى درمجموع مى توان بان استنباط كرد كه MCT در كاهش TAF كارآمدتر بوده است.
با توجه به اينكه اندازه اثر يكك متغير رتبهاى است، براى مقايسه اندازه اثر درمانها در مراحل مختلف انفه

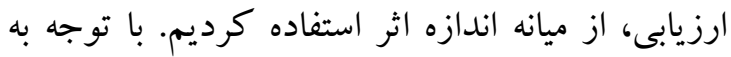

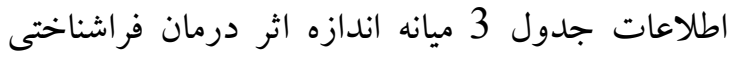
براى كاهش نمره باورهاى فراشناختى، در مرحله بِ

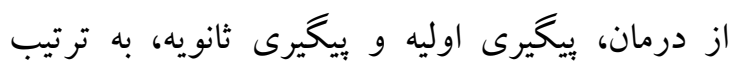
3/29، 6 و 14/49 بوده است و اندازه اثر درمان شناختى -رفتارى در اين متغير در مراحل بس از درمان،

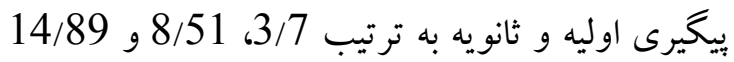
است. ظاهراً به نظر مىرسد كه در اين متغير، درمان

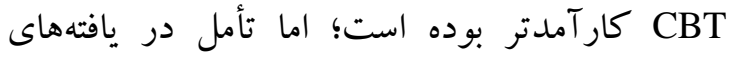

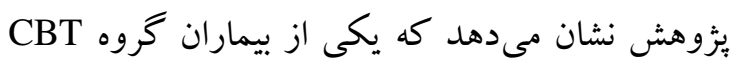
هيج تغييرى در باورهاى فراشناختى نداشته است. از

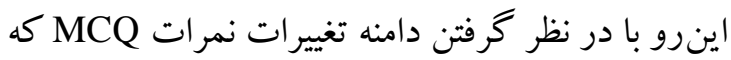

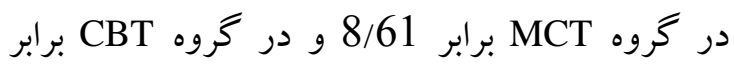


- 69/23 CBT رفتارى در مورد كاهش نمرات كنترل فكر و حفظ

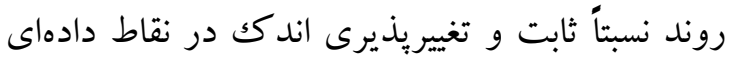
كار آمدتر عمل كرده است. ميانه اندازه اثر براى متغير برآورد خطر در مرحس مرحلى بعد از درمان براى گروه MCT و CBT به ترتيب برابر با 31/25 و 27/27 است. به نظر مىرسد درمان فراشناختى در كاهش نمرهى برآورد خطر موفقتر بود.

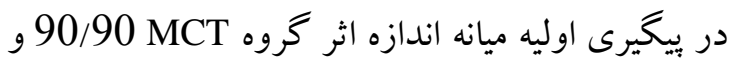
كروه CBT 70 بر آورد شد؛ بنابراين در اين مرحله نيز

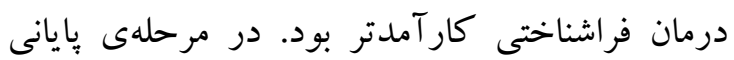
ارزيابى، درمان شناختى - رفتارى كار آمدى بيشترى در كاهش نمر ات بر آورد خطر نشان داد. در نهايت براى تحليل گروهى دادهها از روش تحليل واريانس با يكك عامل بين گروهى (كروههاى درمانى) و يكك عامل درونى (زمان آزمونها شامل بيش آزمون، بس آزمون، بيخيرى اوليه و بيگيرى ثانويه)

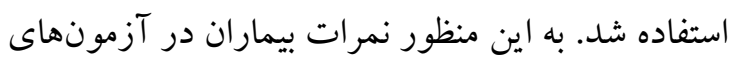

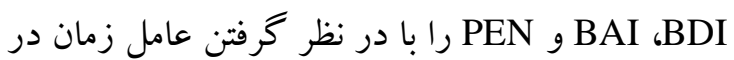
دو گروه CBT و MCT مقايسه كرديم كه نتايج آن در جدول 4 نشان داده شده است.

جدول 4 نشان مىدهد كه اثر زمان در تمام متغيرهاى نمره بيمار در TAF MCQ، نشانهاى توقف درونى، كنترل فكر و برآورد خطر معنادار است. البته اثر گروه نيز در تمام اين متغيرها جزء TAF، معنادار

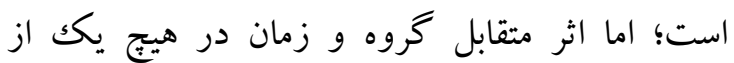
متغير ها معنادار نيست.
ميانه اندازه اثر درمان فراشناختى در كاهش نمرهى نشانهاى توقف درونى در مرحلهى اول ارزيابى، 44/30 و اندازه اثر درمان شناختى - رفتارى در همين مر حله، 42/85 است. مشاهده مىشود كه اندازه اثر در كروه MCT، با تفاوت بسيار جزئى بالاتر است. در مرحلهى بيخيرى اوليه، ميانه اندازه اثر گروه MCT، 44/30 و ميانه اندازه اثر CBT، 60 است. به نظر مى رسد كه در درمان شناختى - رفتارى در تداوم درمان

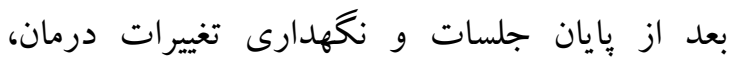
كارآمدتر بوده است. ميانه اندازه اثر در مرحلهى ييخيرى ثانويه در گروه MCT، تقريباً 44 و ميانه اندازه اثر براى گرووه CBT، 60 است. دامنهى تغييرات درو درو كروه MCT، 7/5 و CBT، 130/55 است. از سوى ديخر تغييريذيرى نقاط دادهاى در گرووه CBT زياد است؛ بنابراين در يكك جمعبندى كلى درمان دران فراشناختى كار آمدتر به نظر مىرسد. ميانه اندازه اثر درمان فراشناختى در كنترل فكر در بـر مرحلهى بعد از درمان 19/23 و ميانه اندازه اثر درمان شناختى - رفتارى در اين مرحله برابر با 26/92 است.

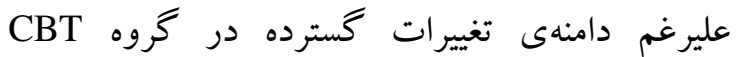

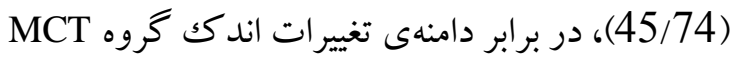

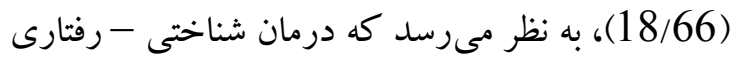
در مرحلهى بعد از درمان موفق تر بوده است. در مرحلهى بعدى ارزيابى ميانه اندازه اثر MCT همان 18/66

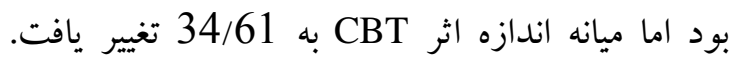
ازاينرو به نظر مىرسد در اين مرحله نيز CBT موفقتر عمل كرده است. در آخرين مرحلهى ارزيابى ميانه

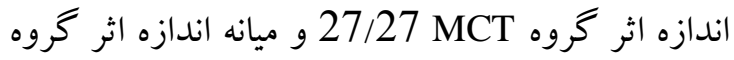


جدول 4: خلاصه آمارهها و نتايج تحليل واريانس جندعاملى براى دو كروه با MCTو و CBT

\begin{tabular}{|c|c|c|}
\hline اثر متقابل خروه و زمان & اثر خروه & اثر زمان \\
\hline
\end{tabular}

\begin{tabular}{|c|c|c|c|c|c|c|c|c|c|c|c|c|c|}
\hline Sig & $\overline{d f}$ & $\bar{F}$ & Sig & $\overline{\mathrm{Df}}$ & $\bar{F}$ & sig & $\overline{d f}$ & $\bar{F}$ & معيار & ميانگين & انحراف & ميانكين & $\begin{array}{c}\text { زاندازهيرى } \\
\text { زمان }\end{array}$ \\
\hline \multirow{5}{*}{0.406} & \multirow{5}{*}{3} & \multirow{5}{*}{1.051} & \multirow{5}{*}{0.002} & \multirow{5}{*}{1} & \multirow{5}{*}{$\begin{array}{c}48.92 \\
1\end{array}$} & \multirow{5}{*}{0.008} & \multirow{5}{*}{3} & \multirow{5}{*}{6.358} & 11.240 & 56.67 & 18.502 & 50.67 & بيش آزمون \\
\hline & & & & & & & & & 11.240 & 56.67 & 18.502 & 50.67 & پֶس آزمون \\
\hline & & & & & & & & & 14.224 & 52.67 & 14.640 & 45.67 & يّيخيرى 1 \\
\hline & & & & & & & & & 18.248 & 49 & 30.116 & 33 & بيخيرى 2 \\
\hline & & & & & & & & & 303.699 & 263.33 & 251.642 & 393.33 & بيش آزمون \\
\hline \multirow{3}{*}{0.104} & \multirow{3}{*}{3} & \multirow{3}{*}{2.556} & \multirow{3}{*}{0.052} & \multirow{3}{*}{1} & \multirow{3}{*}{7.468} & \multirow{3}{*}{0.008} & \multirow{3}{*}{3} & \multirow{3}{*}{6.42} & 230.290 & 196.67 & 102.144 & 213.33 & يֶ آزمون \\
\hline & & & & & & & & & 219.317 & 190 & 77.675 & 193.33 & ييخيرى 1 \\
\hline & & & & & & & & & 147.162 & 196.67 & 105.987 & 113.33 & يسيكيرى 2 \\
\hline \multirow{5}{*}{0.6} & \multirow{5}{*}{3} & \multirow{5}{*}{0.646} & \multirow{5}{*}{0.001} & \multirow{5}{*}{1} & \multirow{5}{*}{$\begin{array}{c}78.29 \\
4\end{array}$} & \multirow{5}{*}{$0 . . \cdot 1$} & \multirow{5}{*}{3} & \multirow{5}{*}{$\begin{array}{c}10.64 \\
4\end{array}$} & 11.846 & 28.67 & 7.024 & 40.67 & ييش آزمون \\
\hline & & & & & & & & & 8.737 & 12.67 & 5 & 24 & ֵِس آزمون \\
\hline & & & & & & & & & 6.245 & 9 & 2.646 & 21 & بيخيرى 1 \\
\hline & & & & & & & & & 9.713 & 11.67 & 12.342 & 13.67 & بيخيرى 2 \\
\hline & & & & & & & & & 5.132 & 24.67 & 3.512 & 22.33 & ييش آزمون \\
\hline \multirow{3}{*}{0.331} & \multirow[t]{3}{*}{3} & 1.264 & 0.002 & 1 & 48.81 & 0.000 & 3 & 21.67 & 9.018 & 18.33 & 4.583 & 17 & حֶس آزمون \\
\hline & & & & & & & (5 & 3 & 2.060 & 3.43 & 1.674 & 1.53 & يُيخيرى 1 \\
\hline & & & & & & & & & 12.220 & 10.67 & 6.110 & 17.33 & ييخيرى 2 \\
\hline & & & & & & & & & 8 & 18 & 3.606 & 15 & بيش آزمون \\
\hline 0.762 & 3 & 0.391 & 0.005 & 1 & 32.90 & 0.000 & 3 & 23.01 & 7.550 & 12 & 4.041 & 10 & ֵِ آزمون \\
\hline & & & & & & 1 & 3 & 7 & 10 & 17 & 4.583 & 17 & يِيخيرى 1 \\
\hline & & & & & & & & & 1.155 & 0.67 & 1.732 & 2 & ي يِيرى 2 \\
\hline & & & & & & & & & & & & MCQ & 1. نمره بيم \\
\hline & & & & & & & & & & & & TAF & 2. نمره بيما \\
\hline & & & & & & & & & & & ف درونى & شانهـ & 3. نمره بيم \\
\hline & & & & & & & & & & & & كنترل & 4. نمر \\
\hline & & & & & & & & & & & & $T$ & \\
\hline
\end{tabular}




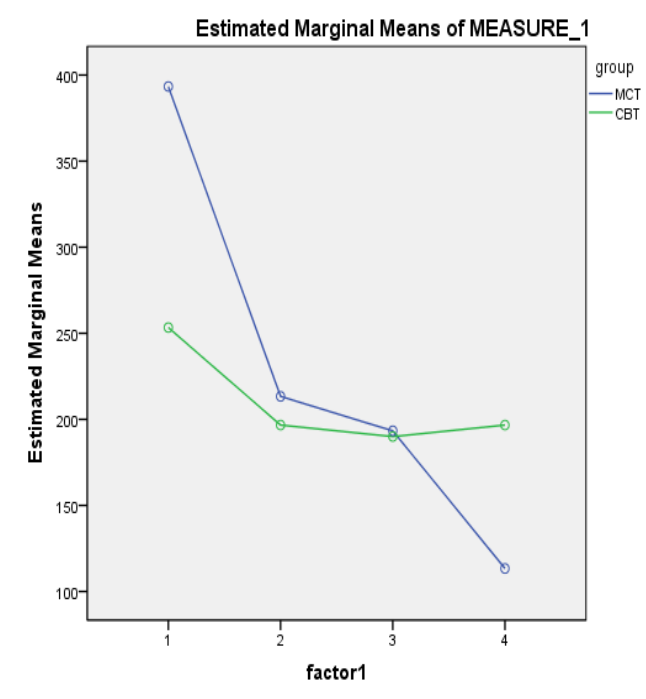

شكل 7: مقايسه دو كروه در نمرهى TAF در زمانهاى اندازهكيرى

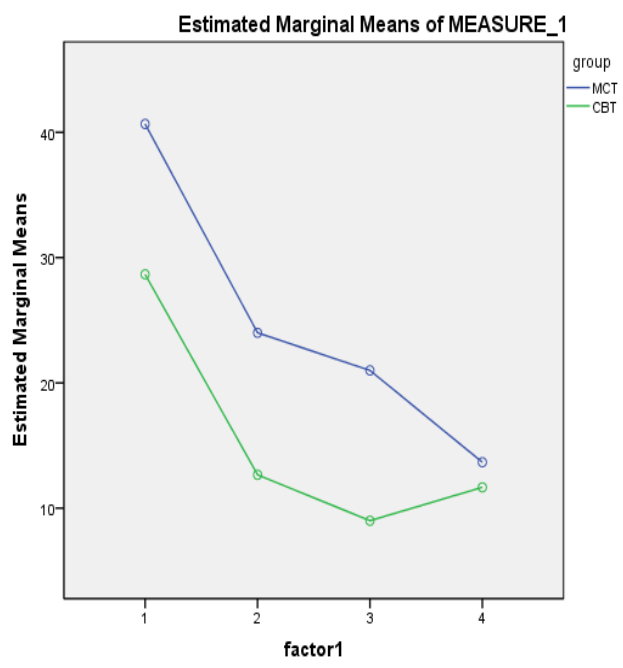

شكل 9: مقايسه دو كروه در نمرهى كنترل فكر،

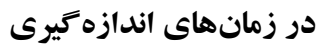

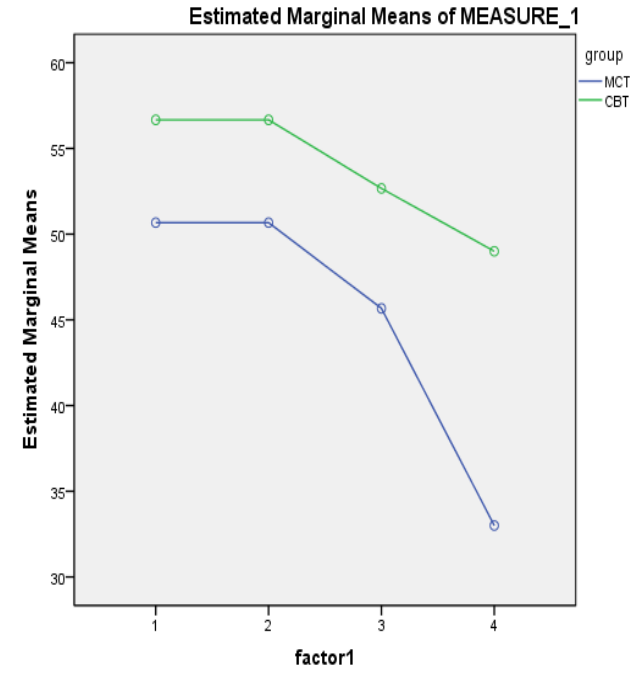

شكل 6: مقايسه دو كروه در نمرهى MCQ، در زمانهاى اندازه مئى

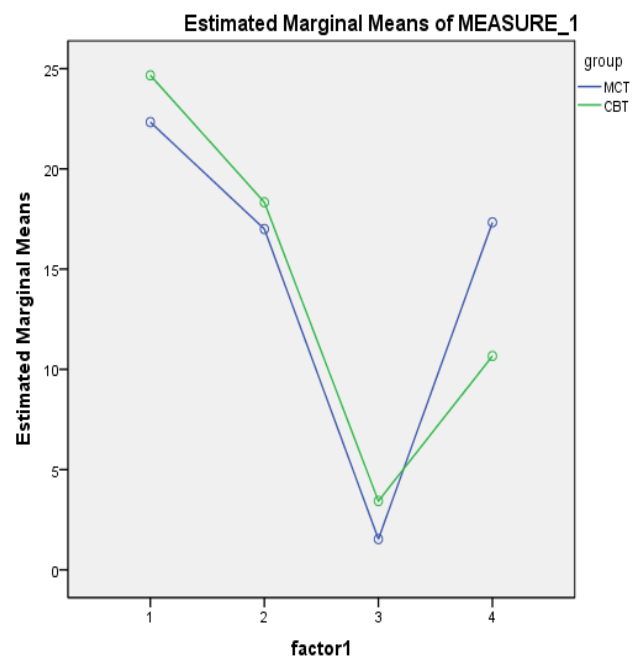

شكل 8: مقايسه دو كروه در نمرهى توقف درونى،

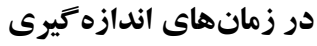

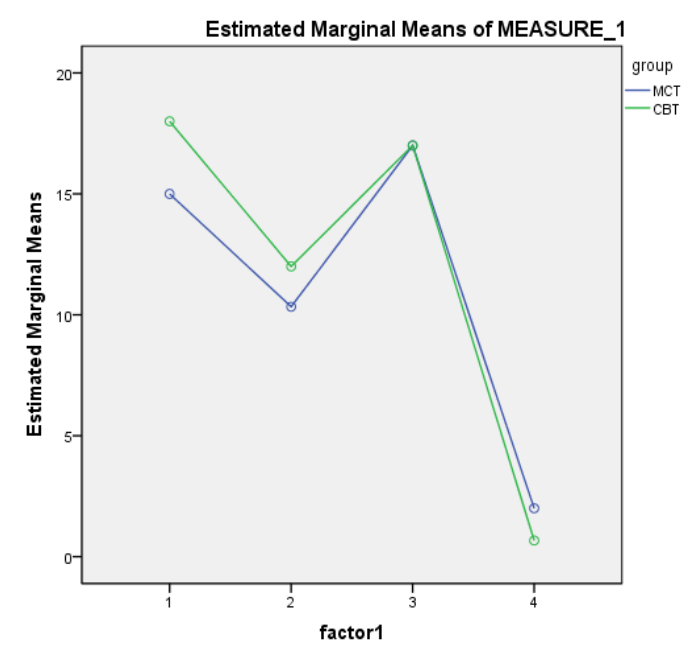

شكل 10: مقايسه دو كروه در نمرهى بر آورد خطر، در زمانهاى اندازه كيرى

مجله رو انشناسى و روان بزشكى شناخت، سال بنجم، شماره 1، بهار 1397، 17-1 
نشانهاى درونى توقف استفاده شد. در درمان بحث و نتيجه كيرى

شناختى -رفتارى، درمانگر براى جالش با بيش بر آورد خطر، از تكنيك محاسبه احتمال عواقب خطرناك (ون آين و همكاران، 1994) و براى جالش با كنترل فكر از تكنيكهاى سود و زيان، روش تحقيق و و

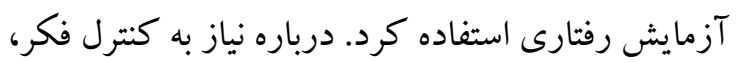

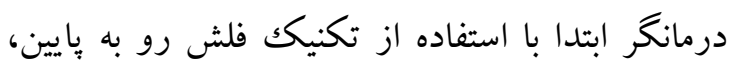

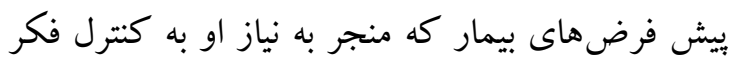

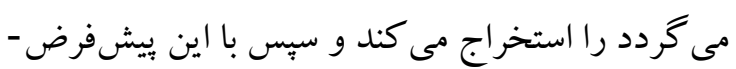

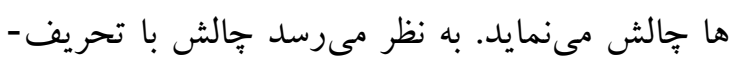

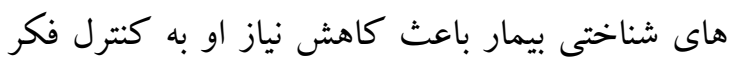
مىشود. تبيين ديخر از كار آيى بيشتر درمان CBT در كاهش

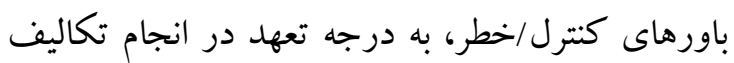
مربوط مىشود. درمان فراشناختى از طريق ايجاد تغيير در توجه غير منعطف و متمركز بر خود، تغيير در سبك له

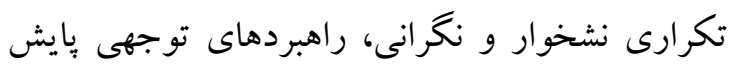

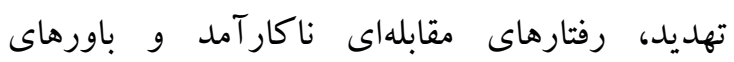
فراشناختى تنظيم كننده اين فر آيندها به درمان بيماران وسواسى مىيردازد؛ بنابراين اولين قدم در درمان بيماران وسواسى هدايت آنها براى يكك جهت گيرى فراشناختى و كنار كذاشتن سبك عينى است. در همين راستا از تمرينات مداوم ذهن آكاهى و رويارويى و انجام باسخ استفاده مىشود. در بُزوهش حاضر بيماران كروه CBT تعهد و تلاش بيشترى براى اجراى تكاليف

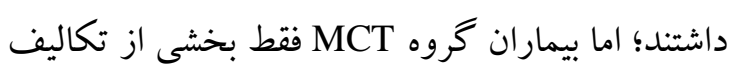
خود را انجام مىدادند؛ بنابراين اين احتمال وجود دارد كه تفاوت در كار آمدى اين دو درمان ناشى از عدم تبحر در مهارتهاى فراشناختى به دليل كوتاهى در اجر اى تكاليف باشد.

در جمعبندى نهايى مىتوان گفت وسعت تغييرات ايجادشده درنتيجه MCT بيش از CBT است. MCT

در بثزوهش حاضر به مقايسه كارآمدى درمان

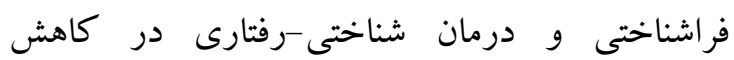
باورهاى فراشناختى، باورهاى آميختكى، توقف درونى

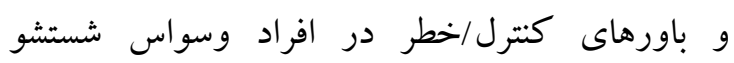
برداختيم. يافتهاى كلى بزوهش حاكى از آن آن است كه در مورد كاهش باورهاى فراشناختى، باورهاى آميختكى و نشانهاى توقف درونى، MCT كار آمدتر از CBT است. البته اين كارآمدى در مورد باورهاى آميختخى معنادار نبود. در مورد كنترل فكر و برآورد الينه خطر، درمان شناختى -رفتارى به شكل معل معنادارى كار آمدتر از درمان فراشناختى عمل كرد. اين يافتهها همسو با ادبيات يزوهشى درمان OCD است. فيشر و همكاران (2008) و خرمدل و همكاران (1389) نشان دادند كه به كار گيرى درمان فراشناختى در كاهش نمره آميختخى افكار بيماران مبتلابه OCD مؤثر است. همجنين در يُزوهش اندوز و همكاران (2012) نمره

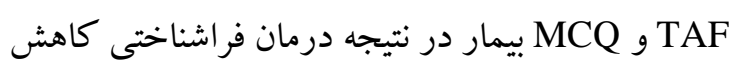
يافت. عبدالله زاده و همكاران (1390) نيز نشان دادند كه MCT بيش از دارو درمانى در كاهش MCQ مؤثر است. يثوهش فيروز آبادى و همكاران (1388)، اثربخشى ذهن آكاهى گسليده را در كاهش باورهاى

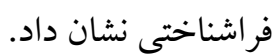
در تبيين اين يافتها بايد به نقش مكانيزم درمان

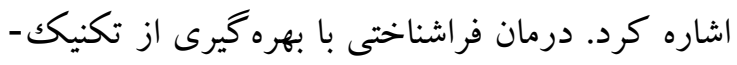

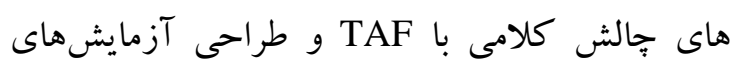
رفتارى براى آن و نيز ERP مبتنى بر MCT در باسي

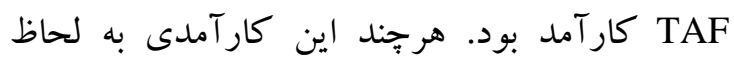
آمارى معنادار نبود. راهنماى درمانى MCT اين دهرجين بُزوهش، از جلسه سوم تا بايان درمان به اين فنون

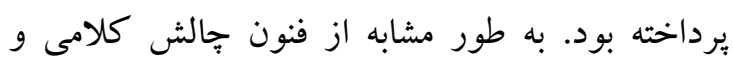

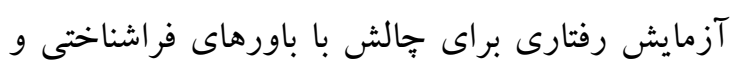




$$
\begin{aligned}
& \text { كارآمدى نسبى داشت. در حالى كه CBT در حوزه- } \\
& \text { هاى محتو ايى شناخت كار آمدتر بود. }
\end{aligned}
$$

\section{References}

Abdollazadeh, F., Javanbakht, M., Abdolazadeh, H. (2011). The compare of metacognitive therapy and

pharmacotherapy in patient with obsession. Journal of Sabzevar University of Medical Sciences. 18(2): 110-118. [Persian].

Abramowitz, J. S. (2006). The Psychological Treatment of ObsessiveCompulsive Disorder. The Canadian Journal of Psychiatry-In Review, 51 (7), 407-416.

American Psychiatric Association (2013). Diagnostic and statistical manual of mental disorders, 5th Ed. Arlington, VA, American Psychiatric Association.

Andouz, Z. Dolatshahi, B., Moshtagh, N., \& Dadkhah, A. (2012). The Efficacy of Metacognitive Therapy on Patients Suffering from Pure Obsession. Iran Journal Psychiatry, 7, 11-21.

Ayat mehr, F. (2013). Comparative Efficacy of Metacognitive therapy versus Cognitive- Behavioral therapy on washing Obsessive-Compulsive Disorder. Master's thesis. Kharazmi University. [Persian].

Barrett, P. M., Farrell, L., Pina, A. A., Peris, T. S., \& Piacentini, J. (2008). Evidence-based psychosocial treatments for child and adolescent with obsessivecompulsive disorder. Journal of Clinical Child and Adolescent Psychology, 37(1), 131-155.

Eddy, K. T., Dutra, L., Bradley, R., \& Westen, D. (2004). A multidimensional meta-analysis of psychotherapy and pharmacotherapy for obsessivecompulsive disorder. Clinical Psychology Review, 24(8), 1011-1030.

Firouzabadi, A., Shareh, H. (2009). Effectiveness of detached mindfulness techniques in treating a case of obsessive

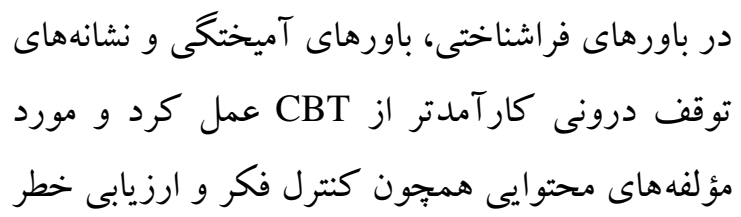

compulsive disorder. Advances in cognitive sciences. 11(2): 1-7. [Persian].

Fisher, P., \& Wells, A. (2011). Book review: Metacognitive Therapy. Journal of Psychosomatic Research, 17: 113.

Foa, E. B., Huppert, J. D., Leiberg, S., Kichic, R., Salkovskis, P. M., Hajcak, G., et al. (2002). The obsessive-compulsive inventory: development and validation of a short version. Psychological Assessment, 14: 485-496.

Freeston, M. H., Ladouceur, R., Gagnon, F., Thibodeau, N., Rheaume, J., Letarte, H., \& Bujold, A. (1997). Cognitive- behavioral treatment of obsessive thoughts: A controlledstudy. Journal of Consulting and Clinical Psychology, 65(3), 405-413.

Gwilliam, P., Wells, A., \& Cartwright-Hatton, S. (2004). Dose meta-cognition or responsibility predict obsessive-compulsive symptoms: a test of the metacognitive model. Clinical Psychology \& Psychotherapy, 11(2), 137-144.

Khoramdel, K., Rabiee, M., Molavi, H., neshatdoust, H. (2010). Psychometric Properties of Thought Fusion Instrument (TFI) in Students. Iranian Journal of Psychiatry and Clinical Psychology, 16 (1): 74 -78. [Persian].

Mataix-Cols, D., Rosario-Campos, M \&, .Leckman, J. (2005). A Multidimentional Model of Obsessive Compulsive Disorder. American Journal of Psychiatry. 162: 228- 238.

Mohamadi, A., Zamani, R., Fata, L. (2008). Validation the Persian version of revised obsessive compulsive questionnaire in students' population. Psychological research. 11, 66-78. [Persian].

Mohammadkhani, Sh. Farjad, M. (2009). The Relationship of the 
Metacognitive Beliefs and Thought Control Strategies with ObsessiveCompulsive Symptoms in Nonclinical Population. Clinical psychology. 1 (3): 35-51. [Persian].

Mohammadkhani, Sh., Mazloum, M. (2010). The Relationship of metacognitive beliefs and thought control strategies with trait anxiety. Contemporary Psychology. 5(2), 23-32. [Persian].

Myers, S. G., Fisher, P. L., \& Wells, A. (2009). An empirical test of the metacognitive model of obsessivecompulsive symptoms: Fusion beliefs, beliefs about rituals, and stop signals. Journal of anxiety disorders, 23(4), 436442.

Ogles, B. M., Lunner, K. M., \& Bonesteel, K. (2001). Clinical significance: History, application and current practice. Clinical Psychology Review, 21, 421-446.

Rees, C. S., \& Van Koesveld, K. E. (2008). An open trial of group metacognitive therapy for obsessivecompulsive disorder. Journal of Behavior Therapy and Experimental Psychiatry, 39, 451-458.

Salkovskis, P. M. (2007). Psychological treatment of obsessive-compulsive disorder. Psychiatry, 6: 6-12.

Salkovskis, P. M., Shafran, R., Rachman, S., \& Freeston, M. H. (1999). Multiple pathways to inflated responsibility beliefs in obsessional problems: possible origins and implications for therapy and research. Behaviour Research and Therapy, 37, 1055-1072.

Salkovskis P. M., \& Westbrook, D. (1989). Behaviour therapy and obsessional ruminations: Can failure be turned into success? Behaviour Research and Therapy, 27, 149-160.

Salkovskis, P. M., Wroe, A. L., Gledhill, A., Morrison, N., Forrester, E.,
Richards, C., \& Thorpe, S. (2000). Responsibility attitudes and interpretations are characteristic of obsessive compulsive disorder. Behaviour Research and Therapy, 38(4), 347-372.

Solem, S., Mayers, S. G., Fisher, P. L., Vogel, P. A., \& Wells, A. (2010). An empirical test of the metacognitive model of obsessive-compulsive symptoms: Journal of Anxiety Disorders, 24: 79-86.

Van Oppen, P., \& Arntz, A. (1994). Cognitive therapy for obsessivecompulsive disorder. Behavior Research and Therapy, 32, 1, 79-87.

Wahl, K., Salkovskis, P. M., \& Cotter, I. (2008). "I wash until it feels right'": the phenomenology of stop criteria in obsessive-compulsive washing. Journal of Anxiety Disorders, 22, 143- 161.

Watson, H. J., \& Rees, C. S. (2008). Meta-analysis of randomized controlled treatment trials for pediatric obsessivecompulsive disorder. Journal of Child Psychology and Psychiatry, 49(5): 489498.

Wells, A., \& Fisher, P. L. (2005). Experimental modification of beliefs in obsessive-compulsive disorder: a test of the metacognitive model. Behavior Research and Therapy, 43: 821-829.

Wells, A., \& Fisher, P. L. (2008). Metacognitive therapy for obsessivecompulsive disorder: A case series. Journal of Behavior Therapy and Experimental Psychiatry, 39(2): 117-132.

Wells, A., Gwilliam, P., \& CartwrightHatton, S. (2001). The Thought Fusion Instrument (unpublished self-report scale). University of Manchester, UK.

Yorulmaz, O. (2007). A Comprehensive model for obsessive compulsive disorder symptoms: a mediated by psychological inflexibility. Unpublished Phd Thesis. School of social sciences: Middle East technical university. 